\title{
DESIGN DE SUPERFÍCIE TÊXTIL: ALÉM DA IMAGEM ESTAMPADA
}

\section{TÂNIA CRISTINA DO RAMO SILVA; FABIANA DOS SANTOS PATRÍCIO}

\author{
Programa de Pós-Graduação em Têxtil e Moda \\ Escola de Artes, Ciências e Humanidades - Universidade de São Paulo \\ Av. Arlindo Béttio, 1000 - 03828-000 - Ermelino Matarazzo - São Paulo - Brasil \\ tania.ramo@usp.br; fabianapatriciodusp.br
}

\begin{abstract}
Resumo. Existiriam características mais notáveis em imagens de estamparias em tecidos que busquem identificar aspectos relevantes em sua composição visual? Este artigo tenta investigar representações imagéticas $e$ simulações ligadas à percepção por meio de conceitos relacionados à imagem. Considerando que a criação da imagem de design de superfície estamparia têxtil - reflete sobre as relações de criação e questões ligadas à composição e sintaxe dos elementos da comunicação visual, destacando questões ligadas à imagem, que é um fator simbólico buscando novas formas de expressão por meio da tecnologia.
\end{abstract}

Palavras-chave: imagem; moda; design de superfície; estamparia têxtil; comunicação.

\begin{abstract}
Would there be more notable features in stamping images in tissues that seek to identify relevant aspects of its visual composition? This article attempts to investigate imagistic representations and simulations linked to perception through concepts related to image. Considering that the creation of surface design image - textile printing - reflects on creation relations and issues regarding composition and syntax of visual communication elements, highlighting issues related to the image that is a symbolic factor seeking new forms of expression through technology.
\end{abstract}

Keywords: image; fashion; surface design; printing textile; communication.

\section{Introdução}

O design de superfície (estamparia têxtil) é uma técnica muito antiga, que possui relação de representação ou simulação por meio de composições imagéticas, visto que a imagem tem ligação direta com a percepção, que é subjetiva a cada indivíduo. Estas imagens produzem ilusões óticas visuais para os mais diversos meios, reverberando o campo da moda que está amplamente conectada ao mundo das imagens e que faz da imagem um conceito inspirador para produzir novas analogias.

\footnotetext{
${ }^{1}$ Mestranda no Programa de Pós-Graduação em Têxtil e Moda - EACH-USP.

${ }^{2}$ Mestranda no Programa de Pós-Graduação em Têxtil e Moda - EACH-USP.
} 
A criação de uma estampa propõe ligações e contextos de harmonia de composição visual dos meios plásticos e estudos dos signos. Sua concepção é feita por meio do módulo (motivo/desenho), produzindo um padrão com os motivos, o que faz surgir, dessa maneira, um padrão, que é conhecido como repetição. Na moda, chama-se rapport (repetição em francês) ou repeat (repetição em inglês), o que dá origem ao design de superfície têxtil, quando repetido diversas vezes em um determinado tamanho.

A estamparia está vinculada à moda e, dessa forma, procura inovações criativas a partir de estudos imagéticos, para valorizar a estética simbólica do vestuário. O desenho é elaborado a partir de estudos de tendências, onde é determinado o objeto-signo que será desenvolvido para compor a nova imagem a ser impressa. O processo construtivo dessa imagem resulta em um repertório original, não só pessoal (bagagem cultural do indivíduo que projeta a estampa), mas também de técnicas muito especificas em estamparias, tecidos, custos e conceitos de moda. A mensagem estampada é composta por conceitos visuais, tendo em vista um objetivo para contar, expressar, explicar, dirigir, inspirar, afetar etc. Na busca de qualquer objetivo se faz escolhas por meio das quais se pretende reforçar e intensificar certa expressão.

Segundo Dondis (2007, p. 131-132), a composição é o meio interpretativo de controlar a reinterpretação de uma mensagem visual por parte de quem a recebe. $\mathrm{O}$ significado se encontra tanto no olho do observador quanto no talento do criador, sedo que o resultado final de toda experiência visual, na natureza e, basicamente, no design, está na interação de polaridades duplas. Primeiro as forças do conteúdo (mensagem e significado) e da forma (design, meio e ordenação); em segundo lugar, o efeito recíproco do articulador (designer, artista ou artesão) e do receptor. Em ambos os casos, afirma o autor, um não pode se separar do outro: a forma é afetada pelo conteúdo, e o conteúdo é afetado pela forma. A mensagem é emitida pelo criador e modificada pelo observador (DONDIS, ibidem; idem).

A imagem estampada na superfície têxtil procura conexões que possam ser percebidas pelo usuário. Estes elementos passam a ser centrais e são portadores de significados, percepções, e precisam fazer sentido além de criar conexões pessoais. Quando isso acontece, é o momento em que o objeto apresenta o gosto e as preferências individuais voltadas às questões técnicas e subjetivas. Assim, como percebemos ou imaginamos algo que nunca vimos? O que percebemos em um desenho têxtil? As novas tecnologias e recursos tecnológicos favorecem essas transformações no conceito da imagem estampada, ou elas provêm de contaminações visuais?

\section{Design de superfície têxtil}

O design de superfície é um conjunto de metodologias e técnicas que permitem transferir imagens para superfícies de produtos. Quando são projetadas estampas para tecidos de moda, por exemplo, trabalha-se reunindo muitas informações e fatores de várias ordens: criativa, tendências de moda ou não, perfil do consumidor, mercado, processos industriais de estampagem disponíveis, relação custo-benefício incluindo conformidade com pressupostos sustentáveis. 
O desenho de estamparia têxtil é destinado à superfície de tecidos e sua elaboração e criação dependem de sintaxe visual, estilos de desenhos, criação do padrão e técnicas de produção específicas (manual, informatizada ou digital), que são recursos determinantes para a produção em pequena ou grande escala. A técnica manual, que é tradicional da Índia, é utilizada até os dias atuais através de carimbos, estêncil e rolos de madeira ou quadros gravados manualmente em telas de poliéster. Já a técnica informatizada abrange o conceito de separação de cores com o auxílio do computador, e geralmente é gravada em cilindros de níquel cromo ou quadros de poliéster no processo rotativo e estampada de maneira direta ou indireta. E, por último, a técnica digital, que conceitua a técnica informatizada ou somente montagens de imagens raportadas. Ou seja, as imagens criadas digitalmente não necessitam de separação de cores, pois a imagem é estampada de maneira direta no tecido por meio de impressora digital. Além das técnicas, são necessários estudos de bases (tecidos) para que as cores impressas estejam conforme Pantone $\AA$, visto que as cores mudam conforme o tecido impresso. As estampas têxteis geralmente são bidimensionais, não sendo esse fato uma regra absoluta, pois já existem no mercado impressoras 3D que modificam a linha do pensamento a partir de novas expressões da imagem.

O design de superfície têxtil é uma composição de relações entre imagem, moda e percepção. As criações buscam ligações que propõem contextos de harmonia de cores e sintaxe visual; sua concepção é feita por meio de módulo, que é a menor unidade visual de um padrão de repetição (figura 1). O módulo, por sua vez, sobrepuja todos os elementos do padrão de repetição, porém, isso não quer dizer que estrutura a maneira com que o padrão se repetirá. Portanto, o módulo pode não ser essencialmente um rapport. Quando o módulo é o rapport, significa que estamos em um sistema de repetição linear (figura 2), o que quer dizer que o módulo se repete linearmente em suas arestas, em bloco, dando um salto completo na vertical e na horizontal. O rapport, em sua composição, é formado por elementos compositivos como: pontos, linhas, cores, texturas, espaços, tensão, respiro, repetição e harmonia. Lembrando que o ponto é a menor unidade visual e a partir dele se produz qualquer forma de percepção visual.

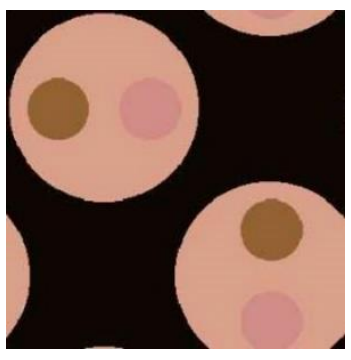

Figura 1. Módulo - menor unidade do padrão ${ }^{3}$.

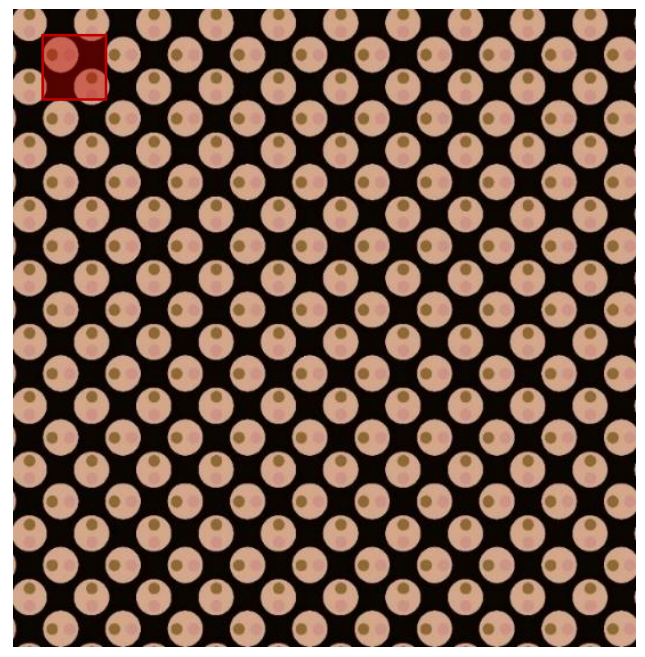

Figura 2. Repetição de rapport linear 4.

\footnotetext{
${ }^{3}$ Figura 1 - Acervo pessoal das autoras.

${ }^{4}$ Figura 2 - Acervo pessoal das autoras.
} 
O design de superfície têxtil aborda uma das áreas criativas imagéticas do processo de elaboração de uma coleção, e, além da pesquisa, possui estrutura extremamente prática. A área do design abrange uma indústria dinâmica que revela novas possibilidades. Este campo disseminou-se e existem muitas ramificações da classe. Em uma sociedade moderna, em que tudo se relaciona com design, valor e estética do produto, pode-se dizer que moda é design.

O desenho de estamparia têxtil nem sempre é representado por uma superfície contínua (rapport), podendo também ser representado de forma localizada (figura 3), onde destaca uma imagem posta em alguma parte da roupa, com as mais diversas técnicas, entre estas, manual, digital ou mista (onde ocorre a mistura de técnicas plásticas e digitais).

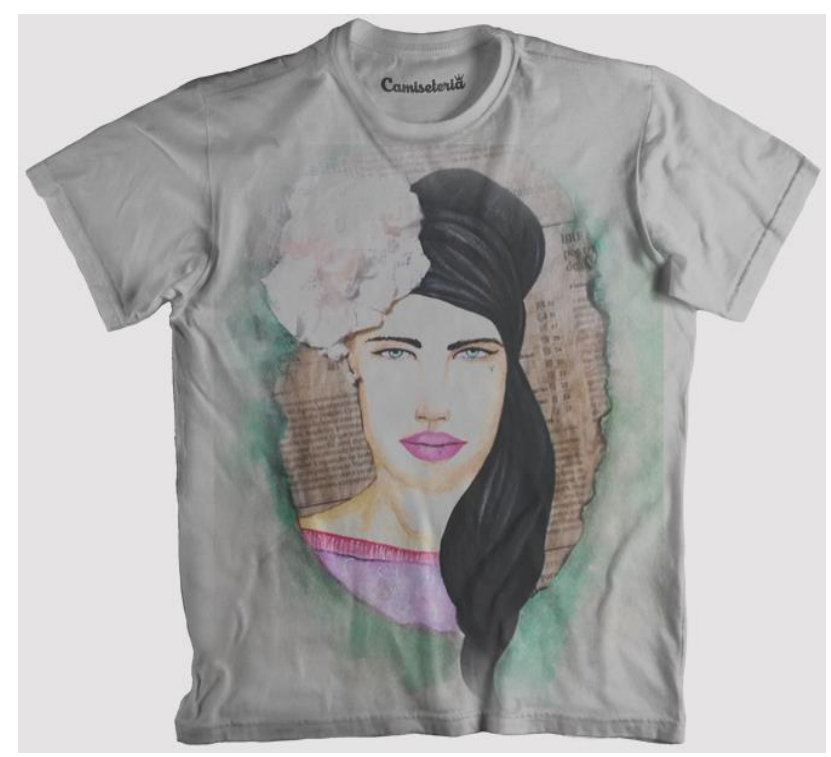

Figura 3. Estampa localizada 5 .

O estilista destaca tendências e propõe os estilos e as estéticas vigentes do momento. E existem estudos muito particulares que definem as tendências de moda. Dentro desse contexto, a questão fundamental é: existiriam aspectos fundamentais que determinariam a composição para a criação de uma estampa têxtil?

A criação de uma estampa abrange elementos, assim como na comunicação visual, e compreende conceitos visuais importantes, como o tipo de rapport (direto, saltado na metade [1/2] ou invertido [1/4], e espelhado); a posição das cores para compor novas variantes ${ }^{6}$; e técnicas de gravação e produção de uma estampa. Os estudos instigam questões pertinentes ao mundo das imagens vestíveis. Dessa forma, a percepção dessas imagens está ligada às sensações que traduzem a sensibilidade ou a intuição, que também reverberam no campo das ideias e da intuição intelectual.

\footnotetext{
${ }^{5}$ Figura 3 - Acervo pessoal das autoras. Estampa desenvolvida com técnica mista - aquarela, colagens, nanquim e digitalizada em Photoshop®.

${ }^{6}$ A palavra "variante", no segmento da moda, simboliza uma nova composição de um conjunto de cores.
} 


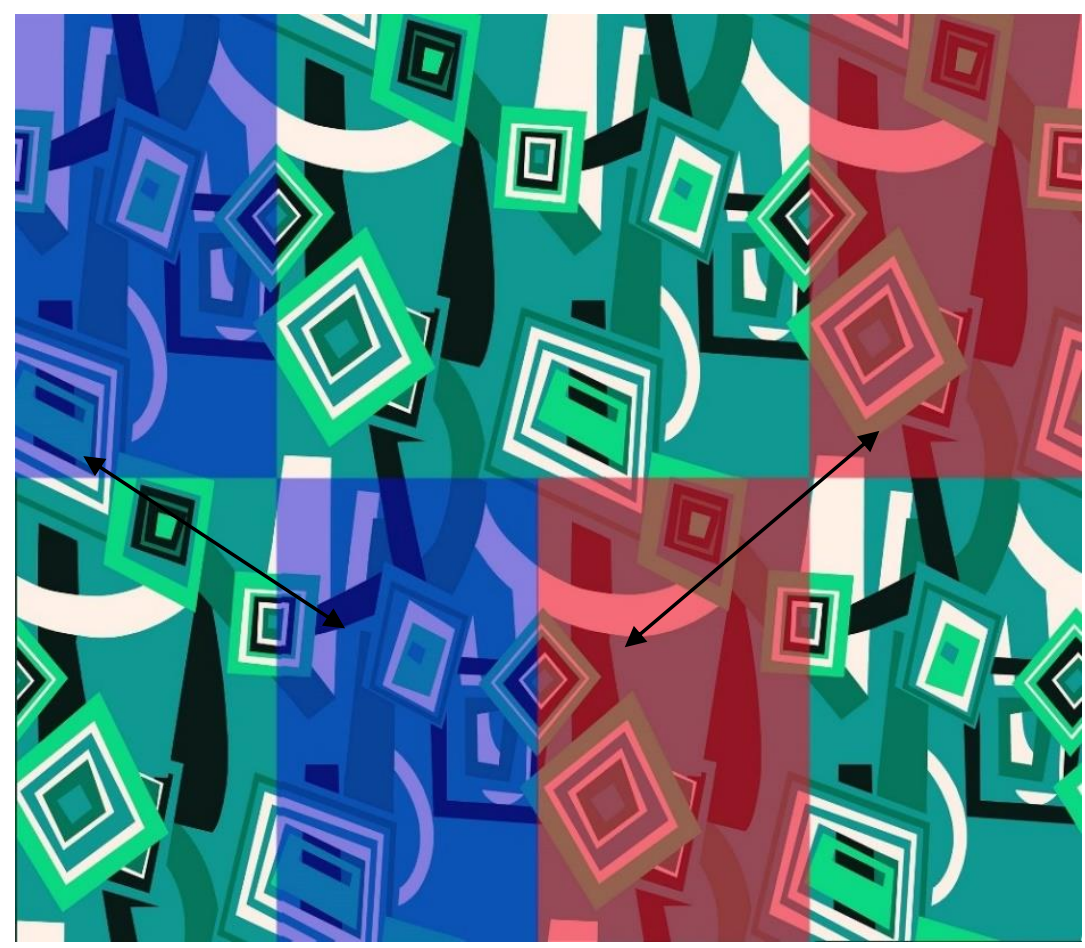

Figura 4. Desenvolvimento do Grid - Rapport Saltado $1 / 27$.

O desenvolvimento da composição do layout para um desenho de estamparia está amplamente relacionado com o "Grid" (figura 4), o que determina que os espaços precisam ser bem definidos na comunicação: temos grades compostas e modulares; há divisão de colunas e formatação de elementos. Na estamparia é bem parecido: existem as composições de motivos (desenhos) ou módulos (desenhos) ( $c f$. figura 5).

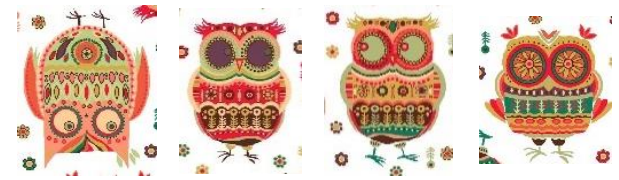

Figura 5a. Vários módulos ${ }^{8}$.

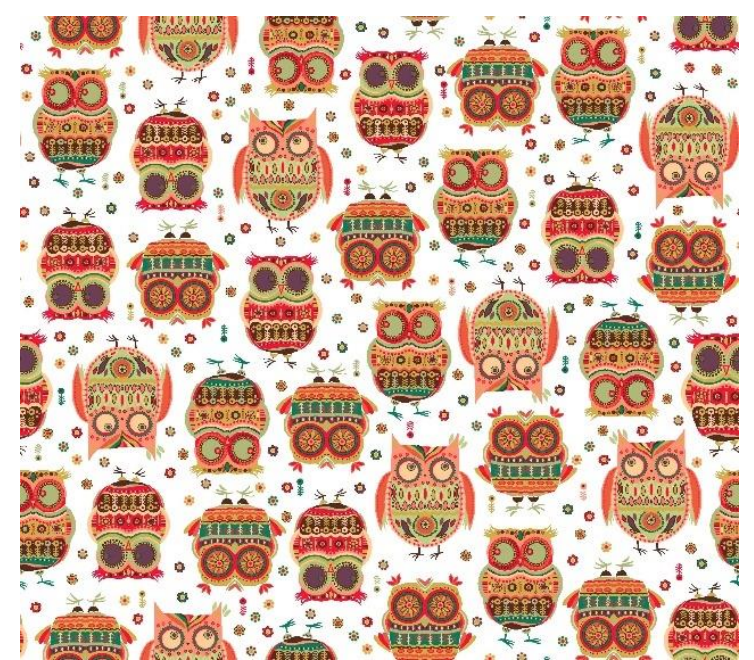

Figura 5b. Repetição de vários módulos em uma composição aleatória ${ }^{9}$.

\footnotetext{
${ }^{7}$ Figura 4 - Acervo pessoal das autoras.

${ }^{8}$ Figura 5a - Acervo pessoal das autoras.

${ }^{9}$ Figura $5 b-$ Acervo pessoal das autoras.
} 
Estudos de tendências e estilos de vida são necessários para conceituar a coleção e desenvolvimento das estampas, originando assim os estilos de cada estação. A estamparia têxtil também pode ser uma prática que se distingue da lógica social voltada para o mercado da moda, onde se destaca o valor estético social sob uma análise simbólica e perceptiva do consumo. A priori, para falarmos de design de superfície, é necessário entendermos o conceito de moda, que é efêmero e complexo para a maioria dos autores, pois a moda segue ritmos e paradigmas ligados ao comportamento e consumo, uma seleção natural de valores e necessidades relacionados ao objeto-signo e voltados à divisão de classe social. Sendo assim, a semântica de "moda" é complexa, visto que não só envolve questões subjetivas, mas também práticas políticas e econômicas. A moda, nesse paradigma, pode ser pensada enquanto um depósito social, no qual simula-se comportamentos, expressões e identidades; um reflexo, portanto, da sociedade na qual está inserida.

\title{
3. Composição da imagem estampada
}

\begin{abstract}
A linguagem é também uma faculdade de conceitualização, de organização do mundo, é, portanto muito mais que a simples comunicação.
\end{abstract}

(BARTHES, 2005, p. 96)

Como podemos dizer que percebemos ou imaginamos algo que nunca vimos? Imaginar é ser capaz de desenvolver imagens com a mente. Em todos os estímulos visuais e em todos os graus da inteligência visual, o significado pode se deparar não apenas com as informações representacionais na informação de tempo e nos símbolos, inclusive a linguagem, mas também nas compositivas, que existem ou coexistem com expressão factual e visual. Qualquer acontecimento visual é uma forma com conteúdo, mas o conteúdo é extremamente influenciado pela importância das partes constitutivas, como a cor, o tom, a textura, a dimensão, a proporção e as relações compositivas com o significado (DONDIS, 2007, p. 22).

Os fundamentos sintáticos são fundamentais para a composição visual, porém não existem regras absolutas que exprimam o sucesso de uma estampa, pois o grau de compreensão é subjetivo e irá acontecer em termos de significado para cada interpretante. São muitos critérios que envolvem o significado na forma visual. Esta, por sua vez, está relacionada ao processo de entendimento e à percepção humana.

A imagem estampada é produzida por um conjunto de informações da linguagem da comunicação que se caracteriza em harmonia visual, destacando ritmo, cor, ênfase, equilíbrio entre os motivos, contornos (filetes), formas, texturas e tipo de rapport. Sua finalidade é a produção e a representação de um desenho para imprimir em um tipo de superfície, neste caso, o tecido, podendo variar em sua composição.

Ruthschilling (2008) define que a composição visual de uma imagem é um conjunto de formas não interrompidas que invocam conceitos da sintaxe visual como tensão e respiro - alternância visual - entre as formas, utilizando-se também da Gestalt (psicologia da forma) como um fundamento necessário à composição, por aplicação de uma de suas regras, como figura e fundo, enquanto recurso de percepção. 
Os dados visuais têm três níveis distintos e individuais: input visual, que consiste de miríades de sistemas de símbolos; material visual representacional, que identificamos no meio ambiente e podemos reproduzir através do desenho, da pintura, da escultura e do cinema; e a estrutura abstrata, a forma de tudo aquilo que vemos, seja natural ou resultado de uma composição intencional. (DONDIS, 2007, p. 20)

As estampas são criadas por meio dos símbolos que remetem à atuação ou composição de elementos, estado de espírito e formas; suas significações vão desde os mais sublimes detalhes representacionais até os inteiramente abstratos. Estes são tão distantes da informação identificável que é necessário entendê-los para apreender o que simbolizam. Na estamparia, é preciso que o olhar seja sincrético para observar as mais variadas composições, mesmo relacionadas à arte; e enxergar o mundo por meio das imagens estampadas para se ter uma visão global do conjunto sem diferenciação.

O desenho de estamparia e a criação de uma propaganda passam por conceitos parecidos, sendo utilizado em sua composição o processo visual em sua forma mais simples, do que resulta a produção de forças visuais para que o receptor consiga conceber a informação. Porém, em um desenho têxtil, existem questões de tendências e públicoalvo, pois são produzidas para fins comerciais de moda; seu contexto, portanto, é subjetivo. Os componentes visuais utilizados em uma estampa são os elementos básicos da comunicação: o ponto, a linha, a forma, o tom, a cor, a textura, a escala proporcional, a dimensão e o movimento. Os elementos visuais são manuseados com evidência pelas práticas de comunicação visual, de maneira direta, mirando o objetivo da mensagem.

O ponto (figura 6) é a menor unidade visual e é o identificador e marcador de espaço. A linha seria o articulador fluído incansável da forma, e, com ela, chega-se a uma forma. A forma possui características que vão das mais básicas (geométricas) às mais infinitas variações (estilizadas, figurativas), até as abstratas. A cor é matiz cromática de valor expressivo e emocional; e o tom representa a ausência ou presença de luz.

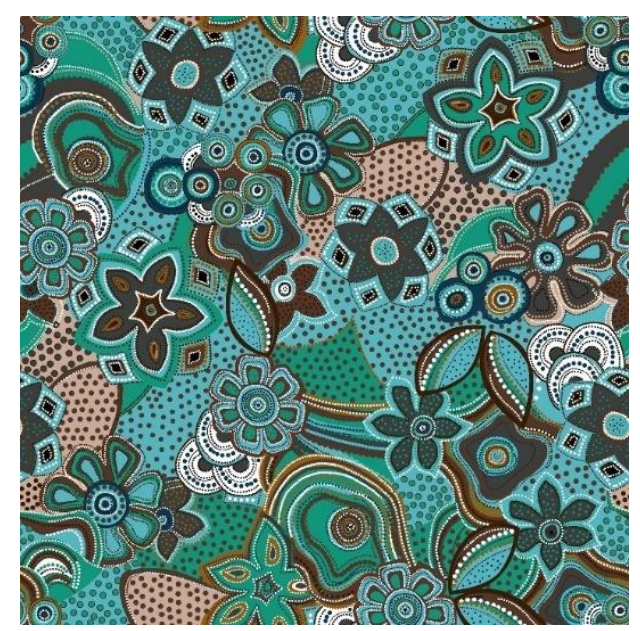

Figura 6. Proporção, equilíbrio e harmonia dos elementos ${ }^{10}$.

\footnotetext{
${ }^{10}$ Figura 6 - Acervo pessoal das autoras. A harmonia é a combinação de elementos compositivos que proporcionam equilíbrio visual ao rapport. Na figura, os pontos (círculos) dão uniformidade e equilíbrio a imagem para evitar buracos (respiros) em determinadas partes do desenho.
} 
As texturas são variações de sensações e podem demonstrar suavidade, aspereza, maciez, rugosidade etc. Variam em sua exposição, podendo ser visual ou tátil. A estamparia é uma representação ou simulação de símbolos e/ou ícones que transparecem em desenhos, buscando passar algum tipo de informação.

O contraste (figura 7) possui característica de contraponto, em que duas áreas são diferentes e dividem o foco de atenção da visão humana. O contraste pode ser por cor, tom ou proporção (valor). Está ligado ao input visual do receptor no espaço ou no tempo.

Escala e proporção são elementos de suma importância na criação de uma estampa, constituindo a medida ou tamanho de cada módulo/motivo a ser distribuído pela estampa. A direção e o movimento são importantes, pois, por meio deles, é possível dar direção e frequência ao motivo/módulo. A partir da manipulação desses elementos, é possível desenvolver uma estampa, visto que o procedimento de composição é a maneira terminante na solução dos problemas visuais (DONDIS, 2007, p. 23).

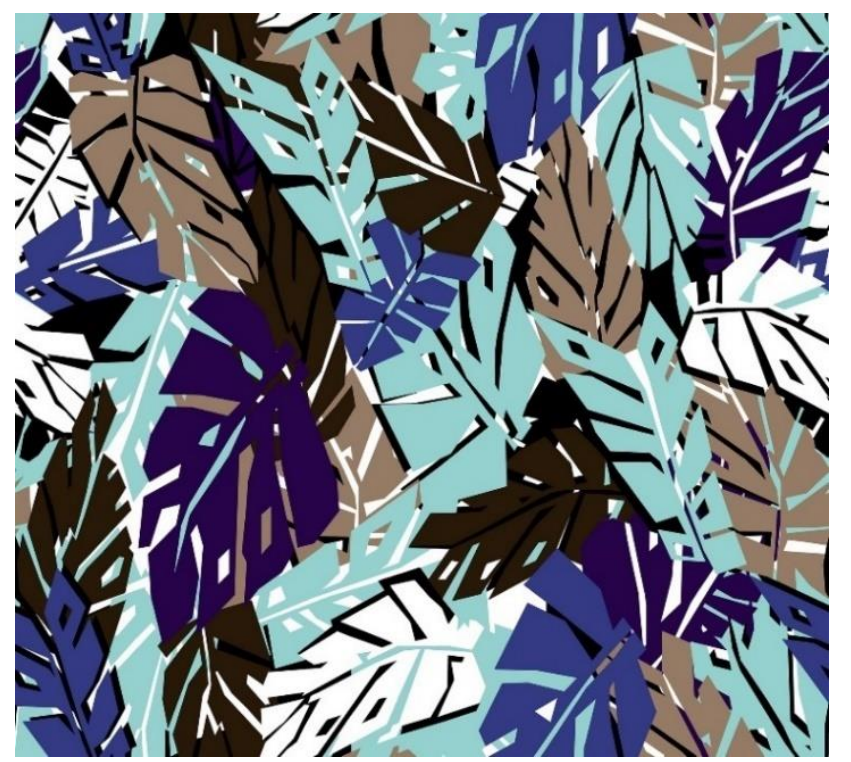

Figura 7. Contraste de cor (luminosidade) e proporção da forma ${ }^{11}$.

A proporção (figura 7) é de suma importância na organização dos elementos compositivos; afinal, para expressar a dessemelhança entre as partes é necessário ocupar a maior proporção a ele destinada. A proporção e a escala dependem da organização do layout proposto, da manipulação do tamanho e do espaço, que pode gerar contraste de justaposição por meio das formas. A harmonia é a aplicação dos elementos compositivos que possuem concordância entre partes (similaridade) de maneira aleatória ou linear, produzindo a sensação visual de unidade e continuidade. $O$ equilíbrio é um dos elementos visuais compositivos mais importantes: sua relevância na distribuição está no valor de importância visual entre dois pesos.

\footnotetext{
${ }^{11}$ Figura 7 - Acervo pessoal das autoras. Proporção por forma são os diferentes tamanhos da mesma forma repetida no rapport; no exemplo, as folhas possuem diferentes tamanhos sem perder a característica que a denomina.
} 
O ritmo (figura 8) é representado por formas geométricas proporcionando a percepção de sequência: as linhas verticais dão a sensação de longitude, produzindo a sensação visual de emagrecimento. Este é um dos conceitos de moda. O ritmo consiste em uma repetição linear que se repete ao longo do desenho. É também um dos recursos que contém mais força visual, conceito este obtido por meio da cor, forma, posição, configuração do espaço e figuras.

Na estamparia, cada parte do desenho se chama "motivo", também conhecido como "módulo" (bloco de desenhos), sendo ajustados a um layout linear, circular ou aleatório, para formação de um rapport. Geralmente, para gravação em cilindros, a medida principal é a altura de $64 \mathrm{~cm}$ para a repetição cilíndrica. Esta medida pode ser ajustada em múltiplos de 64 para desenhos menores. O ritmo não segue uma regra absoluta, podendo ser representado de forma simétrica, assimétrica, crescente ou decrescente. Uma superfície sempre deverá conter um ritmo visual único, gerando informações que compõem outros elementos da sintaxe visual, como texturas, contrastes, ênfases, sobreposições, cores, representações de formas e proporções.
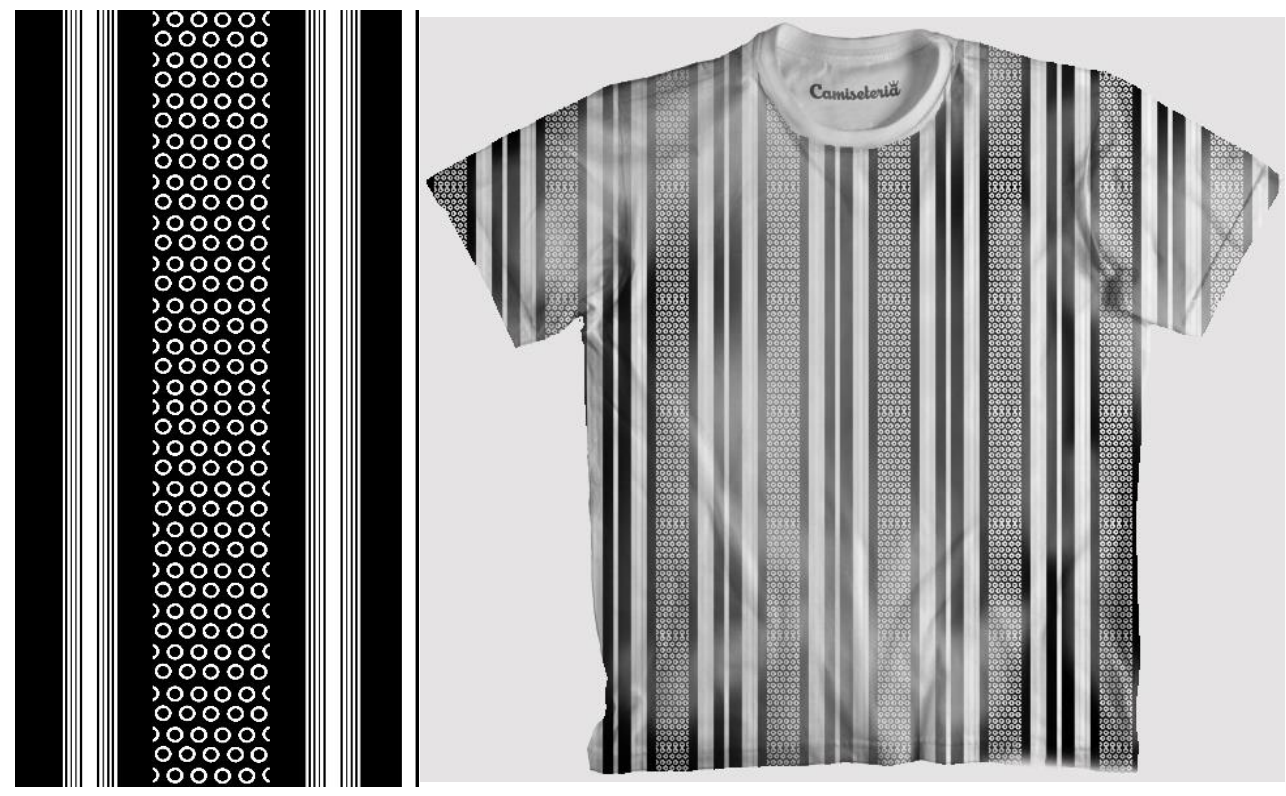

Figura 8. Ritmo em desenho de estamparia12.

Tensão e respiro (figura 9) geralmente são utilizados em um tipo de composição para o desenvolvimento de estampas em que o rapport é composto de maneira mais complexa, sem muitas repetições de módulos. A harmonia visual deste tipo de estampa é produzida na composição geral do rapport e as características deste desenho são de grandes medidas e proporções. A tensão simboliza momentos de agitamento ou uma confusão na percepção dos olhos de quem vê, buscando a composição e linearidade da imagem. O respiro são os espaços destacados entre os elementos de maior preenchimento,

\footnotetext{
${ }^{12}$ Figura 8 - Acervo pessoal autora. Esse tipo de desenho possui característica linear, em que as linhas verticais e os círculos necessitam de tamanhos específicos para o fechamento do rapport, ou seja, a medida necessita ser um múltiplo de 64 centímetros, pois este é o tamanho da altura do cilindro; se for quadro, necessita das medidas do quadro para nele ajustar o desenho.
} 
esses elementos muitas vezes são motivos que não se repetem. As cores utilizadas também podem causar tensão na composição da imagem estampada. A gradação é um tipo de repetição utilizada em um desenho mais complexo, em que o padrão se repete em uma sequência menor de maneira aleatória.

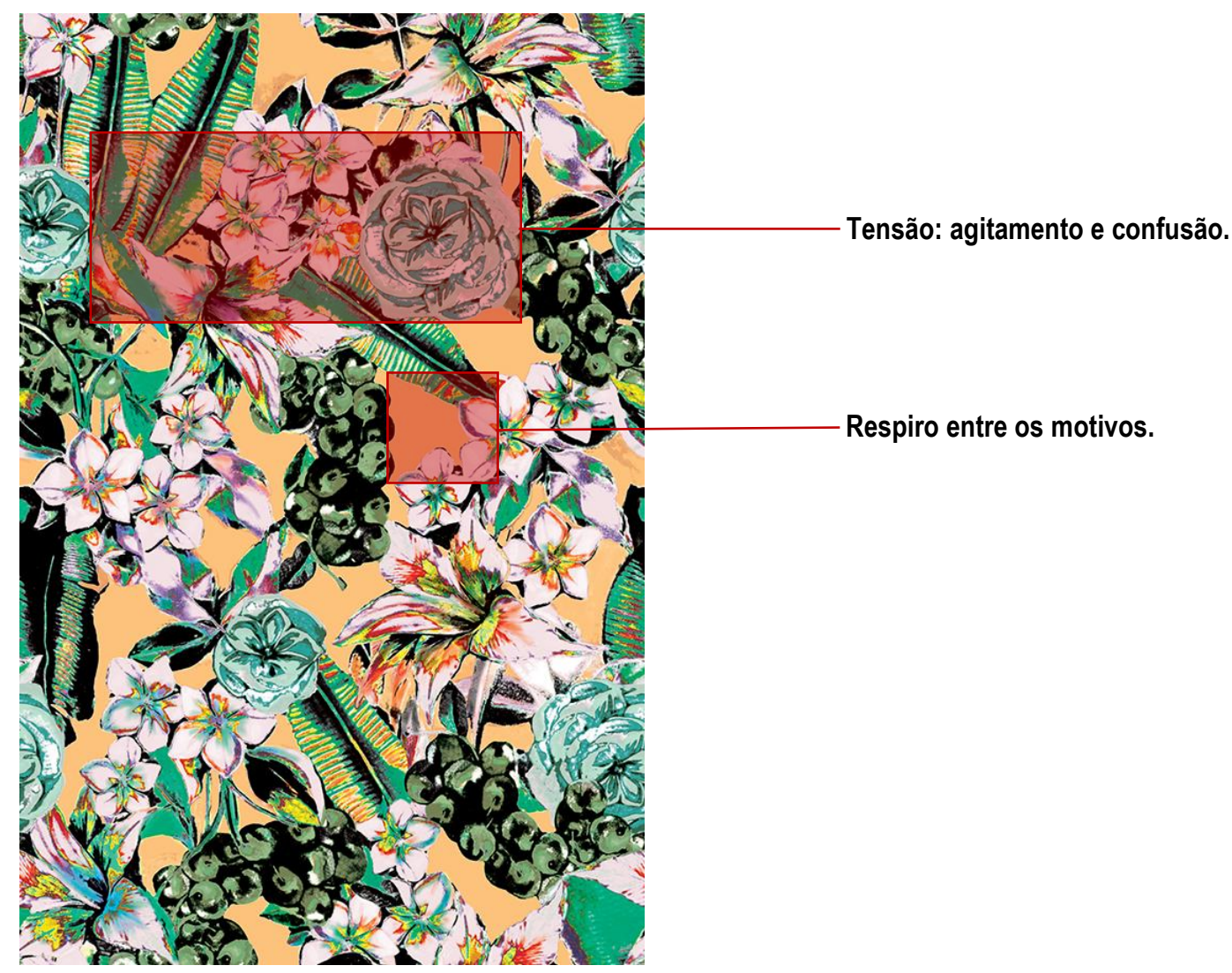

Figura 9. Tensão e respiro ${ }^{13}$.

A formação de conceitos visuais para estamparia parte de qual princípio? Esta pergunta nos coloca no campo das ideias, da percepção visual, do gosto, da simulação, da representação, entre outros fatores, ligados à concepção da imagem. Os designers de estampas buscam informações coerentes e criam novas imagens, transformando-as em estampas e cores destinadas a um determinado público. O sucesso de uma estampa depende da percepção do criador e das informações do life style.

Conforme em Briggs-Goode (2014), as fases mais importantes para o desenvolvimento da imagem para uma estampa são o briefing, que está relacionado ao pedido e às características pré-definidas do cliente ou do estilista, e o brainstorm, que é a explosão cerebral de ideias em que se pesquisam os mapas mentais que traduzem maneiras eficazes para desenvolver objetos, materiais e conceitos, que determinarão a inclusão do produto - da estampa - no mercado.

Rubim (2013) destaca algumas considerações sobre o design de superfície têxtil, ressaltando que é um tratamento da superfície, não sendo superficial, pois existe uma

\footnotetext{
${ }^{13}$ Figura 9 - Acervo pessoal das autoras.
} 
camada aparente externa. $\mathrm{O}$ avanço da tecnologia permite interferências e propriedades com escopos funcionais, estéticos, ilustrativos, educativos, informativos etc. A proposta do designer deve sempre estar voltada às facilidades que devem aproximar-se das produções e processos fabris (chão de fábrica). Ressalta também que a cor é uma maneira de representação de tratamento de superfície.

As imagens em serigrafia determinam estampas espontâneas, fluidas e pictóricas, que podem servir de inspiração ao modo criativo e inovador no design contemporâneo. Durante os anos de 1910, a imagem fotográfica dos estênceis foi introduzida e, quando se popularizou, por volta de 1920, essa técnica destacou a explanação mais maleável de um modelo do que jamais fora adquirido em contexto industrial.

Existem imagens que representam estilos de estampas; ao longo do tempo, algumas delas alcançaram seu espaço, assim como outras que se modificaram com as novas identidades e também com as inovações tecnológicas, como é o caso da estampa "Animal", que antes era constituída de bichos e hoje, conhecida como animal-print, reverbera o conceito de imagem estampada. Os estilos (desenhos) mais conhecidos são: geométricos, florais, figurativos, étnicos, listrados e abstratos.

As técnicas de estamparia têxtil dinamizam várias classificações e uma das mais antigas é o batik, na qual a imagem é estampada (pintada) utilizando-se um produto (insumo) que protege o tecido antes do tingimento. Os métodos para estampar são cilindro e quadro (serigrafia), estêncil, bloco de madeira e digital. Os insumos (tintas) dependem do tecido a ser estampado, podendo ser de termo-transferência (transfer) por sublimação ou reativa. A estamparia digital também permite infinitas possibilidades de manipulação de imagens ou remix de imagens técnicas - o design e a fabricação de estampas projetadas que são desenvolvidas para uma modelagem específica -, gerando uma estampa com sentimento pensado para adequar a imagem ao formato de uma peça de roupa. Isso proporciona aos designers o ensejo de criar e favorecer novas expectativas para elaborar desenhos/estampas mais ousadas, com imagens elaboradas no contorno do corpo ou produtos para interiores. Os diversos métodos de estamparia dependem da herança visual (história e bagagem cultural), para que o designer de estamparia a utilize como ferramenta. Esses processos deliberam o modo como cada estampa será transferida para o tecido.

\section{Além da imagem: a imagem estampada}

Imaginação é a capacidade de fazer e decifrar imagens. (FLUSSER, 2002, p.7)

A imagem estampada representa a ausência do real contextualizado por simbolismos. São imagens que vão além das imagens, transmitindo sensações, desejos e conceitos. A superfície, por si só, é transformada por meio da imagem, e quando tratamos de tecidos estamos lidando com um conjunto de informações. Neste artigo, voltado para a moda, seja qual for o material de produção ou finalidade, muitas vezes, a imagem está ligada à simulação do real, porém de uma forma mais flexível às percepções estéticas. 
O aspecto simbólico proporciona aos produtos identidade que vai ser avaliada pelo consumidor como congruente, ou não, com a sua própria. Produtos entendidos como símbolos servem ao indivíduo para construir significados que causem reações desejadas em outras pessoas. (GARCIA; MIRANDA, 2007, p. 33)

Das concepções das novas imagens surgiu a civilização da imagem, e, em decorrência, uma sociedade que é totalmente imagética, onde quase tudo é representado por meio de imagens, sendo projetadas, impressas ou circulando por meio de outros recursos tecnológicos. Barthes (2005) supõe que a civilização de imagens vem do passado, visto que as imagens provêm da vida cotidiana do homem. $\mathrm{O}$ autor ressalta que a imagem corresponde ao universo moderno e ainda não está compreendida, correndo o risco de ser falseada, visto que a imagem não funciona sem um objeto original e não existe imagem sem linguagem, pois assim poderia se chamar de comunicação logo-icônica (BARTHES, 2005, p. 79).

As percepções imagéticas são estimuladas por sensações que remetem à sensibilidade ou à intuição que a envolve, reverberando o campo das ideias e da intuição intelectual. São questões dialéticas que se caracterizam geralmente por vários meios, não só tecnológicos, mas em composições artísticas manuais, formando novos conceitos ou poéticas da imagem, com a edição e/ou manipulação da imagem, o que põe em destaque reflexões acerca da representação, da simulação e da realidade (figura 10). Destaca-se, ainda, a presença e não presença do real e o hiper-real. São conceitos intrínsecos às inovações da imagem. Assim, as novas tecnologias e recursos tecnológicos favorecem essas transformações no conceito da imagem, na criação de novas produções e na mudança da composição voltados para estamparia.

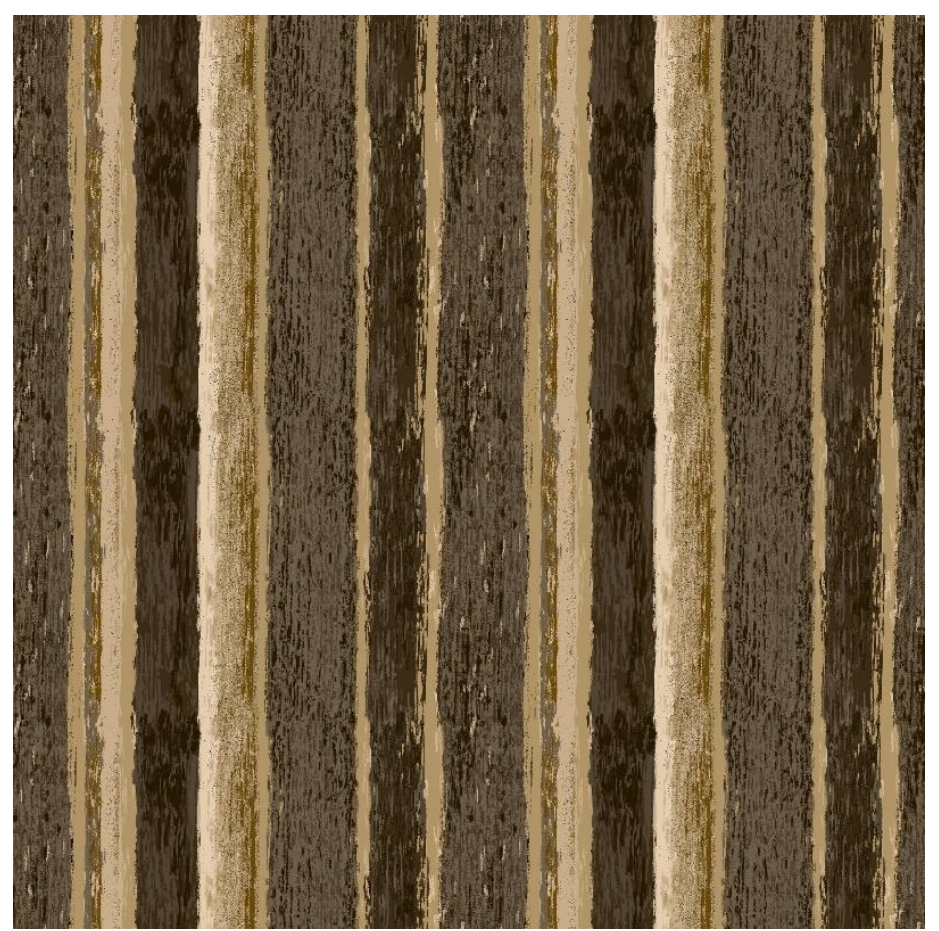

Figura 10. Representação de madeira - manipulação de imagem ${ }^{14}$.

\footnotetext{
${ }^{14}$ Figura 10 - Acervo pessoal das autoras.
} 
Para a imagem estampada, destaca-se o signo plástico: signo completo que remete expressão e conteúdos próprios, no qual o observador une as qualidades plásticas como forma, cor e textura, resultando em significados. Destacam-se aí as leis da comunicação. Os processos não delimitam interpretações, podendo ser os mais variados e mistos, gerando novas percepções por meio da linguagem no sistema visual versus o sistema cognitivo (pelo qual percebemos ou inferimos). A priori, a imagem pode ser uma representação que é apreendida e interpretada; assim toda a representação é um signo, porém, nem todo signo é uma representação. Toda imagem elaborada tem o objetivo de transmitir ou ressaltar informação de alguma espécie; assim, o receptor necessita compreender seus aspectos convencionais, indiciais, icônicos e arbitrários (SANTAELLA, 1997; COUCHOT, 2003).

As novas tecnologias e recursos tecnológicos favorecem essas transformações no conceito da imagem estampada. As questões relacionadas à tecnologia reverberam fatores que Flusser (2002) aborda por meio das imagens técnicas, explicando seu conceito emancipador da sociedade, na maneira ou necessidade de pensar, substituindo a capacidade imaginativa de segunda ordem.

As imagens técnicas (figura 11) são consideradas superfícies que apetecem simular algo com que se depara no espaço e no tempo; assim também é a imagem de moda, que é efêmera e cujo ciclo é destinado conforme o espaço e o tempo relacionados ao produto. As imagens técnicas são elaboradas por meio dos equipamentos, representando a forma de expressão de um indivíduo. Corresponde não só à imagem tradicional, mas também à complexidade da questão da imagem: afinal, a imagem pode ser projetada, representada por meio da linguagem, som, sinestesia, entre outros mecanismos. "As categorias atuais de sociedade, política e arte serão meras defasagens, e o próprio instinto vital, a disposição existencial, irá adquirir um tom novo e exótico para nós" (FLUSSER, 2002, p. 7).

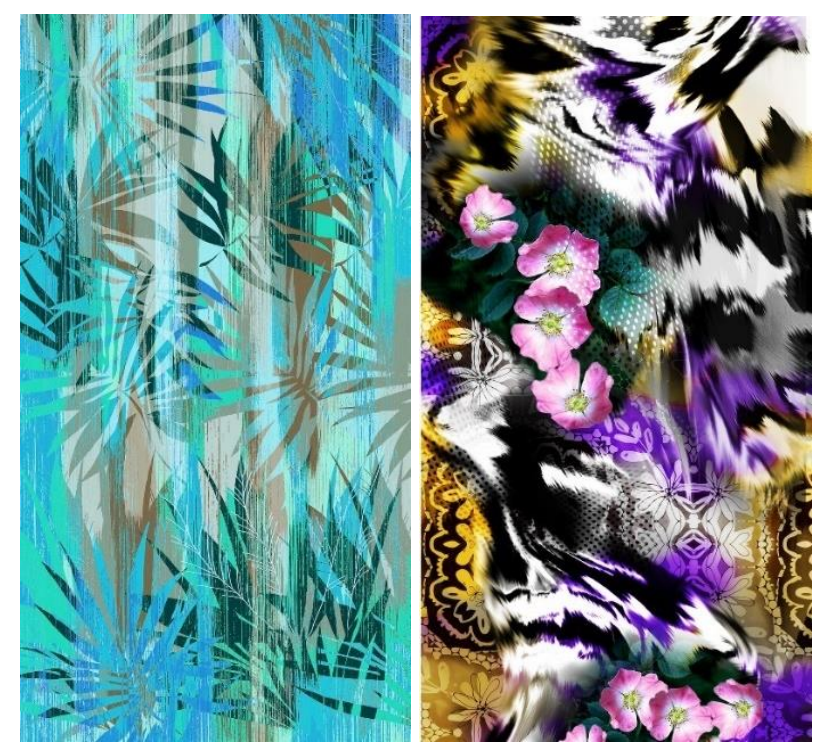

Figura 11. Imagens técnicas; estampas produzidas no computador ${ }^{15}$.

${ }^{15}$ Figura 11 - Acervo pessoal das autoras. 
Para Flusser (2002), as imagens são formas que representam a mediação entre o homem e o mundo, acompanham as transformações dos indivíduos durante suas trajetórias na sociedade, se configuram a partir dos rumos da história e da organização de determinados grupos. Destaca ainda que as imagens são códigos que revelam fatos em ocorrências sendo supridos por cenas. Esclarece também que a imagem tradicional é um devaneio, na qual existem graus de abstração de partes do fenômeno concreto. Ressalta que, enquanto as imagens tradicionais fantasiam o mundo, as imagens técnicas buscam conceitos que idealizam imagens que imaginam o mundo. Essa condição das imagens técnicas é decisiva para serem decifradas. Neste contexto, os desenhos de estamparia se encaixam perfeitamente, visto que a produção técnica da imagem busca suprir a necessidade do mercado, criando ou produzindo novos conceitos de identidade e reverberando a individualidade ou questões de grupo.

Ainda segundo Flusser, para entender uma imagem, é necessário fazer um scanning, ou seja, observar a superfície para poder apreender seu contexto. Assim, Flusser reverbera esse sentimento quando ressalta que a imagem diacroniza a sincronicidade que envolve a questão por empirismo, mas destaca o valor do sentimento e organização das ideias por meio da percepção do olhar divagando o conceito imagético em ciclos. Para o autor, "o significado da imagem é o contexto mágico das relações reversíveis" (FLUSSER, 2002, p. 8).

Já Manguel (2001) ressalta que as imagens podem se expressar como desejos, experiências, questionamentos, vivências e remorso, que estão presentes no subconsciente, muitas vezes, sentimentos ou vazios que utilizamos para complementar as imagens. Durand (2004), por sua vez, refere-se à crítica historicista, que não deixa de recorrer aos conceitos das ciências, da literatura (a gramatologia, a semântica, a fonologia etc.), a partir da qual a análise "poética" da imagem se perde na pluralidade antropológica, que é "monoteísta" e caracterizada por uma estrutura abstrata. Dessa maneira, as obras são repercutidas de imagens simbólicas, incorporando certa incidência biográfica de seu tempo: nelas ocorre a liberação criadora da "poética-da-obra", trazendo revelações sobre o autor e seu tempo.

Assim, a imagem estampada vem agregando estudos peculiares sobre o valor estético simbólico e cultural. O processo construtivo da imagem resulta também em repertório original e pessoal, em que o real pode não ser igual para todos sujeitos. É uma representação singular de composições simbólicas de um processo semântico. O sujeito cria uma imagem em potencial entre vivências e experiências. Assim, adentra-se no campo da composição imagética para a estamparia, reverberando conceitos, estilos e novas formas de representação para a imagem estampada. A partir da contextualização social que envolve a experiência, valor sentimental, organização de ideias, percepção e também a antropologia, a imagem estampada também produz dialéticas de maneira harmoniosa com as mudanças da sociedade, revelando a busca permanente de novas concepções que se adaptem ao gosto pessoal e ao mercado de moda. "Qualquer acção, qualquer imagem é, de certo modo, criadora de realidade. Temos por vezes tendência para considerar a arte como um sistema de significações substituível por outros, pela linguagem ou pela técnica, por exemplo" (FRANSCATEL, 1983, p. 64).

A imagem estampada na superfície têxtil busca junções que possam ser percebidas pelo usuário; estes elementos passam a ser centrais e são portadores de significados, o 
que resulta de uma primeira percepção. Quando isso acontece, é o momento em que o objeto apresenta o gosto e as preferências individuais voltadas às questões técnicas e subjetivas. Flusser (2002) argumenta que a imagem é superficial e está integrada à realidade e à linguagem, sendo que a imagem está conectada à imaginação de codificar e decodificar. $\mathrm{O}$ olhar vagueia em círculos pela imagem (superfície) e tende a voltar sempre para os elementos preferenciais, desacatando conceitos como o tempo de magia, que explica que as imagens criam situações reversíveis. Assim, a mudança de interesse no conceito causa mudança na percepção. A primeira percepção de uma imagem estampada é somente o notar e, logo depois, é o ver, mas isso não significa que há entendimento do conceito proposto e que pode ou não transfigurar a realidade. Na imagem estampada o que mais deveria se destacar seria o rapport, porém, nem todos os indivíduos conseguem entender ou capturar a parte técnica: veem primeiramente o desenho em si, depois as cores, e, por fim, o modelo da roupa.

Todo objeto possui qualidades que lhes são atribuídas e refletidas por meio de percepções. Couchot (2013) afirma que o progresso das técnicas de figuração sugere constância em análises investigativas mais profundas para automatizar cada vez mais os métodos de criação e reprodução da imagem. Nesse contexto, a imagem estampada (moda) reflete a obsessão em produção de novas imagens geradas automaticamente, pois a indústria da moda é uma fábrica de conceitos gerados por comportamentos e estilos de vida, transformados em imagens produzidas para o consumo imediato, seja ela induzida pelo conceito trickle down ou bubble-up. Então, quanto menos intervenções manuais, mais rápido é o processo de criação das novas imagens. Couchot ainda estabelece que toda imagem é numeralizada, perdendo, por isso, toda conexão com o real, embora o simule, pois, o objeto real é preexistente ao pixel. A simulação corresponde ao modelo que define as imagens estampadas, e os módulos seriam um grupo de "desenhos", a partir do qual, pré-organizados em um layout, cria-se uma imagem para uma superfície.

Desse modo, partimos do pressuposto de que a imagem leva a questões que compõem a liberdade visual, leva à busca por inferências ou referências convencionais, arbitrárias e icônicas, que fazem parte da subjetivação de praticamente tudo, não delimitando sensações. A percepção está associada a modelos onde se representa conceitos, simulações e representações, ou pode corresponder apenas a imagens tradicionais produzidas para um determinado fim, segundo composições da linguagem visual. Relacionamos essas questões representativas às leis da comunicação. A imagem estampada de moda necessita de referentes para ser produzida e entendida pelo receptor, não somente pelas formas, mas também pela concepção das cores, estilos, formas, conceitos, estilos de vida e questões da composição visual.

\section{Conclusão}

Afinal, é possível identificar características ou aspectos mais notáveis em imagens de estamparias de tecidos para vestuário de moda que divergem das percepções dos usuários por meio da imagem? Conforme alguns autores, trata-se de uma questão muito subjetiva, em que tudo parece poder ser considerado devaneio da mente que leva o indivíduo para um mundo imagético da representação e de valores estéticos possíveis de serem encontrados/reconhecidos em uma peça de roupa. Existem, segundo esses autores, 
muitas influências que interferem no entendimento da imagem. O sujeito observa a priori o desenho, em seguida, as cores e modelo da roupa, porém, é um processo instantâneo e imediato. Toda a composição de design que envolve formas, cores, grid e informações de comportamento fazem parte de um conjunto formador de interpretações relativas ao objeto em questão e tudo isso está ligado à percepção.

A imagem estampada apresenta não só junção de imagens, mas também atrelamentos com a imaginação, percepções, questões relacionadas ao gosto, àquilo que é oferecido no/pelo mercado, além de técnicas importantes para sua composição visual voltada ao consumo ou à representação social por meio da moda. A imagem não pode ser falsa ou verdadeira. Ela pode receber o estatuto do real, mas sempre será a imagem representada, aquela que não se opõe ao real, de modo que se possa considerar que não há real se não houver imaginação. Mas, com tantas teorias, o que se deve repercutir é a forma sublime pela qual a imagem nos representa, sendo ela fantasiosa, real ou hiper-real, pois, é impraticável encontrar um nível incondicional do real tanto quanto uma ilusão total.

As técnicas de estamparia têxtil evoluíram desde os carimbos à estamparia digital, e as formas de composições ganharam novas evidências com a linguagem visual. A harmonia visual é imprescindível para a composição da imagem de estamparia, em que o rapport está conectado a um dos elementos visuais para seu fechamento. Esses elementos são de suma importância para o design; e para o design de superfície não seria diferente. A tecnologia também é grande aliada à formação de novas percepções imagéticas, visto que as manipulações transcendem a realidade, configurando simulacros sempre embasados pelo repertório visual do criador e das tendências de moda que repercutem no momento.

Muitas vezes, a estampa na superfície têxtil busca conexões com os seus usuários, mesmo que sejam de caráter subjetivo. O designer de estampas busca, quando é criação, significados que possam ser percebidos pelos receptores/usuários. É claro que em muitas dessas tentativas, isso não acontece, visto que a busca por objetos de desejo faça com que as questões mínimas sejam desapercebidas.

A percepção na estampa geralmente busca junções ou conexões que devem ser percebidas, sendo que a primeira percepção decorre da presença de elementos centrais, podendo ser o estilo das estampas (florais, animal-print, geométricos), as cores ou o modelo da roupa. Isso reverbera a questão da composição da estampa, que é essencial, destacando as preferências individuais do sujeito, pois, a moda está totalmente integrada à realidade e à linguagem visual dos objetos. Sendo assim, a imagem estampada é uma síntese de seu conceito primário, e, desse modo, reverbera a representação, a simulação e a imitação. A imagem percebida pode, muitas vezes, em um mesmo momento, não apresentar o mesmo sentido para todos os indivíduos, pois o valor concebido é subjetivo. Porém, esse conceito inicial é transformado.

A sociedade contemporânea é imagética e vive um período onde a informação e a comunicação não encontram limites, tudo é muito efêmero. O fato é que a imagem hoje tem papel fundamental e de grande influência no cotidiano. Assim, todas as mídias estão conectadas e interligadas a certo tipo de informação, equipamentos e formações de novas concepções imagéticas, sendo essas tradicionais ou técnicas. As campanhas publicitárias 
estão cada vez mais informais e abusam do valor imagético. A internet e as imagens de moda são as mais significativas e subjetivas, na maioria das vezes objetivando o estímulo a alguma forma de consumo.

Por fim, é fundamental que a experiência visual humana seja melhor compreendida, para que se possa, em decorrência, compreender o meio em que o homem vive e reagir face às suas transformações. A informação visual é o mais antigo registro da história humana, afinal, toda percepção se baseia em uma abstração, para depois aferir e consolidar o significado da imagem. É a busca de significados entre o concreto e o abstrato que fortalece o conceito que leva ao discernimento entre o tempo e espaço. A imagem é um paradigma que demuda, sendo ela concebida espontaneamente ou por meios tecnológicos, que interagem de modo a causar alterações na função da imagem para a qual tenha sido destinada.

\section{Referências bibliográficas}

BARTHES, Roland. Imagem e Moda. São Paulo: Martins fontes, 2005.

BRIGGS-GOODE, A.Design de estamparia têxtil. Porto Alegre: Bookman, 2014.

DONDIS, A.D. Sintaxe da linguagem visual. $3^{\mathrm{a}}$ ed. São Paulo: Martins Fontes, 2007.

FABRIS, Annateresa. Redefinindo o conceito de imagem. Rev. Bras. Hist., São Paulo, v.18, n. 35, 1998. Disponível em

$<$ http://www.scielo.br/scielo.php?script=sci_arttext\&pid=S0102-01881998000100010 $>$; acesso em junho 2015.

FLUSSER, Vilém. O universo das imagens técnicas. São Paulo: Annablume, 2008.

Filosofia da caixa preta - ensaios para uma futura filosofia da fotografia. $2^{\mathrm{a}}$. ed. Rio de Janeiro: Relume Dumará, 2002.

FRANSCATEL, Pierre. A imagem, a visão e a imaginação. Lisboa: Edições 70, 1983.

FREYRE, G. Modos de homem e modas de mulher. Rio de Janeiro: Record, 1997.

GARCIA, C.; MIRANDA, A.P. de. Moda é comunicação - experiências, memórias, vínculos. 2a . ed. São Paulo: Editora Anhembi Morumbi, 2007.

LAURENTIZ, S. Questões da imagem. Disponível em $<$ http://www.agnusvalente.com/hibrida/silvialaurentiz_texto_01.htm >; acesso em mar. 2015.

MACHADO, Arlindo. A simulação da imagem. Em: Máquina e imaginário: o desafio das poéticas tecnológicas. São Paulo: EDUSP, 1993. (pp. 59-112). 
NIEMEYER, L. Elementos de semiótica aplicados ao design. Rio de Janeiro: 2AB, 2009.

RUBIM, R. Desenhando a superfície. São Paulo: Edições Rosari, 2004.

RÜTHSCHILLING, E.A. Design de superfície. Porto Alegre: Ed. da UFRGS, 2008.

SANT'ANNA, Mara Rúbia. Teorias de moda: sociedade, imagem e consumo. São Paulo: Estação das Letras e Cores, 2009.

SVENDSEN, Lars. Moda: uma filosofia. Rio de Janeiro: Zahar, 2010.

Artigo recebido em: janeiro de 2016.

Aprovado e revisado em: junho de 2016.

Publicado em: agosto de 2016

Para citar este texto:

SILVA, Tânia Cristina do Ramo; PATRÍCIO, Fabiana dos Santos. Design de superfície têxtil: além da imagem estampada. Entremeios [Revista de Estudos do Discurso], Seção Estudos, Programa de Pós-graduação em Ciências da Linguagem (PPGCL), Universidade do Vale do Sapucaí, Pouso Alegre (MG), vol. 13, p. 15-32, jul. - dez. 2016.

DOI: http://dx.doi.org/10.20337/ISSN2179-3514revistaENTREMEIOSvol13pagina15a32 